\title{
Antioxidant and Free Radical Scavenging Activity in Roots of Hygrophila schulli (Buch.-Ham.) M.R.Almeida \& S.M. Almeida
}

\author{
Murugan $\mathrm{S}^{1 *}$ and Kumar $\mathbf{G V}^{2}$ \\ ${ }^{1,2}$ Department of Botany, Government Arts College for Men, Krishnagiri, Tamil Nadu, India
}

Available online at: www.isroset.org

Accepted: 09/Aug/2018, Online: 30/Aug/ 2018

\begin{abstract}
Nowadays herbal medicines form an important part of health care system, due to lots of side effects and complications in the modern medicine. The novel compounds synthesized in plants as secondary metabolites are the potential source of therapeutical uses. Plants produced significant amount of novel compounds to prevent the oxidative stress related diseases and can be used as antioxidant. One such attempt had been made in the present study in investigating the roots of Hygrophila schulli member of acanthaceae family for an antioxidant activity. The roots of H.schulli were extracted using petroleum ether as a solvent. Various assays such as DPPH (1,1-diphenyl 2-picryihydrazyl) free radical, ABTS radical cation, Phosphomolybdeunm reduction assay and ferric reducing power activity were checked for the antioxidant ability and free radical scavenging activity. In all these assays the root extract of H.schulli showed maximum reducing activity of free radical scavenging activity. The IC 50 value of the root extract in each assay was compared with the standard value of ascorbic acid and found Hygrophila schulli has a strong antioxidant and free Radical Scavenging Activity.
\end{abstract}

Keywords: Hygrophila schulli, antioxidant, Free radical, DPPH, ABTS, Phosphomolybdeunm, Fe3+

\section{INTRODUCTION}

Hygrophila schulli (Buch.-Ham.) M.R.Almeida \& S.M. Almeida an important medicinal plant belonging to the family Acanthaceae is distributed throughout India. H. auriculata (K. Schum) Heine and Astercantha longifolia (L.) Nees are the Synonyms of Hygrophila schulli [1]. This plant grows in water shed areas, like agriculture fields, tanks and ditches. This plant has been widely used in traditional medicine which date back to period of Ayurveda, Sidha, Unani etc. In ayurveda it is mentioned as Ikshura, Ikshugandha, and Kokilaaksha [2]. In Unani it is mentioned a Talmakhana and in Sidha it is mentioned as Neermulli [2]. In phytochemical analysis it is found that the roots of $H$. schulli contain Lupeol as major phytocompound, which is active compound in treating various diseases $[3,4,5]$.

The World Health Organization (WHO) has estimated that $80 \%$ of the human population still relies on herbal medicine for their health care and for their daily use [6]. The active novel compounds present in the plants are responsible for the therapeutic property [7]. Nowadays the effects of oxidative stress on human health is a serious issue, during stress human body produce more reactive oxygen species (ROS) which leads to cell damage and health problems such as liver damage, cardiovascular diseases, inflammatory diseases neurodegenerative diseases, cancers etc $[8,9,10]$. In treatment of these diseases, antioxidant therapy has gained immense importance [11]. However the use of synthetic antioxidant lead to adverse effect, for this reason the interest in use of Plant as natural antioxidant has increased [12, 13, 14]. Medicinal Plants are the potential antioxidants which prevent oxidative damage by free radical and ROS.

This article deals with the research on antioxidant activity of the roots of $H$. schulli. The medicinal plant selected for the present study and the importance of antioxidant is briefly mentioned in Introduction Section of this article followed by the objective of the study. The plant collection, plant part extract preparation procedure using suitable solvent and various methodology used in investigating roots of $H$. schulli for antioxidant activity has clearly mentioned in Methods and Methodology Section. The results observed in various investigation is neatly tabulated and for clear understanding of the results it is represented with Graphs. The results are thoroughly discussed by comparing with previous works in Results and Discussion Section. Finally the article is concluded with recommendation in Conclusion Section. 


\section{MATERIALS AND METHODS}

\subsection{The plant collection}

The fresh plant $H$. schulli were collected from the periphery of paddy filed in Alappatti village, Krishnagiri district, Tamil Nadu, India. Authentic identification of the plant was done by Botanical Survey of India, TNAU, South zone Coimbatore, Tamil Nadu.

\subsection{The plant extracts preparation}

The healthy plant roots of $H$. schulli were collected and sterilized by standard surface sterilization method. The roots were separated and dried in shade at room temperature till it was completely dried and were ground in to coarse powder. The root extract was prepared using petroleum ether as a solvent in soxhlation instruments. The obtained extract was vacuum dried and the concentrated extract was stored at $4^{\circ} \mathrm{C}$ in an airtight container for further processing [2].

\subsection{ANTIOXIDANT ACTIVITY}

\subsubsection{DPPH Radical scavenging activity}

The antioxidant activity of $H$. schulli roots were measured on the basis of the scavenging activity of the stable 1,1-diphenyl 2-picryihydrazyl (DPPH) free radical with the slight modification of standard procedure [15]. $1 \mathrm{ml}$ of 0.1 $\mathrm{mM}$ DPPH solution in methanol was mixed with $1 \mathrm{ml}$ of various concentrations $H$. schulli root extract in petroleum ether $(10-120 \mu \mathrm{g} / \mathrm{ml})$. The mixture was then incubated in dark for about 30 minutes. Mixer of $1 \mathrm{ml}$ methanol and $1 \mathrm{ml} \mathrm{DPPH}$ solution was used as the control and Ascorbic acid was used as reference standard. The variation in absorbance was measured using UV-Vis spectrophotometer at $517 \mathrm{~nm}$. The percentage of inhibition was calculated the following formula.

\subsubsection{ABTS $^{\bullet+}$ Radical scavenging activity}

The antioxidant capacity was determined in terms of the $\mathrm{ABTS}^{\bullet+}$ radical cation decolorization assay. $\mathrm{ABTS}^{\bullet+}$ radical cation was produced by the reaction between $7 \mathrm{mM}$ of ABTS and $2.45 \mathrm{mM}$ potassium persulfate in water and stored in the dark at room temperature for 12-16 $\mathrm{h}$ before use. The ABTS solution (stable for 2 days) was diluted with $5 \mathrm{mM}$ phosphate-buffered saline ( $\mathrm{pH}$ 7.4) to an absorbance at $734 \mathrm{~nm}$ of $0.70 \pm 0.02$. To various concentrations (10-60 $\mu \mathrm{g} / \mathrm{ml}$ ) of petroleum ether extract in root of $H$. schulli, with $500 \mu \mathrm{L}$ of diluted $\mathrm{ABTS}^{\bullet+}$ solution was added and incubated at room temperature $10 \mathrm{~min}$. the absorbance was measured at
$734 \mathrm{~nm}$. Ascorbic acid was used as reference standard. The $\mathrm{ABTS}^{\bullet+}$ radical cation scavenging activity was expressed as $\%$ of $\mathrm{ABTS}^{\bullet+}$ radical cation inhibition and calculated using the standard formula [16].

\subsubsection{Phosphomolybdenum reduction assay}

The antioxidant capacity of $H$. schulli root in petroleum ether extract was assessed by phosphomolybdenum reduction method [17]. The root extract of $H$. schulli in different concentration $(20-120 \mu \mathrm{g} / \mathrm{mL})$ was combined with $1 \mathrm{ml}$ of reagent solution containing ammonium molybdate $(4 \mathrm{mM})$, sodium phosphate $(28 \mathrm{mM})$ and sulphuric acid $(600 \mathrm{mM})$. The reaction mixture was incubated in water bath at $95^{\circ} \mathrm{C}$ for $90 \mathrm{~min}$. After, the mixture was cooled to room temperature and the absorbance of the colored complex was measured at $695 \mathrm{~nm}$. The percentage of reduction was calculated using the standard formula

\subsubsection{Ferric $\left(\mathrm{Fe}^{3+}\right)$ reducing power assay}

The $\mathrm{Fe}^{3+}$ reducing power of $H$. schulli root in petroleum ether extract was determined by using potassium ferricyanide assay method with slight modification [18]. One $\mathrm{mL}$ of root extract of different concentrations $(20-120 \mu \mathrm{g} / \mathrm{mL})$ was mixed with $1 \mathrm{~mL}$ of phosphate buffer $(0.2 \mathrm{M}, \mathrm{pH} 6.6)$ and $1 \mathrm{~mL}$ of potassium ferricyanide $\left[\mathrm{K}_{3} \mathrm{Fe}(\mathrm{CN})_{6}\right](1 \% \mathrm{w} / \mathrm{v})$ solution. The mixtures were then incubated at $50^{\circ} \mathrm{C}$ for $30 \mathrm{~min}$ in a water bath. Five hundred $\mu \mathrm{L}$ of trichloroacetic acid (10\% w/v) was added and shaken well followed by $100 \mu \mathrm{L}$ of freshly prepared $\mathrm{FeCl}_{3}(0.1 \%$ w/v) solution was added and shaken well. The absorbance was measured at $700 \mathrm{~nm}$ and the percentage of reduction was calculated.

\section{RESULTS AND DISCUSSION}

\subsection{DPPH Radical scavenging activity}

The roots of H.schulli in petroleum ether extract was assessed using 1, 1- diphenyl 2-picryihydrazyl (DPPH) for scavenging free radicals at $517 \mathrm{~nm}$. DPPH is a nitrogen centered free radical, color of which changes from violet to yellow on reduction, reducing capacity is increased with increasing the concentration of the extract. The maximum percentage of DPPH radical scavenging activity was $93.91 \pm 6.57$ at 120 $\mu \mathrm{g} / \mathrm{mL}$ concentration as shown in Table 3.1 and Graph 3.1. It was compared with the standard ascorbic acid 6.42 $(\mu \mathrm{g} / \mathrm{mL})$ and $\mathrm{IC}_{50}$ of DPPH radical scavenging activity was $51.84(\mu \mathrm{g} / \mathrm{mL})$ Concentration. The scavenging ability of petroleum ether extract of roots of H.schulli may be due to the bio compositions of phenolic acids and flavonoid [19]. 
The DPPH activity of the root extract of H.schulli was compared with the earlier work in seed extract of H.schulli and found similar pattern of antioxidant ability [20].

Table 3.1. DPPH Radical scavenging activity

\begin{tabular}{|c|c|c|}
\hline S. No. & $\begin{array}{c}\text { Concentration } \\
(\boldsymbol{\mu g} / \mathbf{m L})\end{array}$ & \% of inhibition \\
\cline { 3 - 3 } & 20 & DPPH at 517 $\mathbf{~ m m}$ \\
\hline 1 & 40 & $21.28 \pm 1.48$ \\
\hline 2 & 60 & $38.58 \pm 2.69$ \\
\hline 3 & 80 & $63.18 \pm 4.42$ \\
\hline 4 & 100 & $85.50 \pm 5.98$ \\
\hline 5 & 120 & $99.52 \pm 6.26$ \\
\hline 6 & & \\
\hline
\end{tabular}

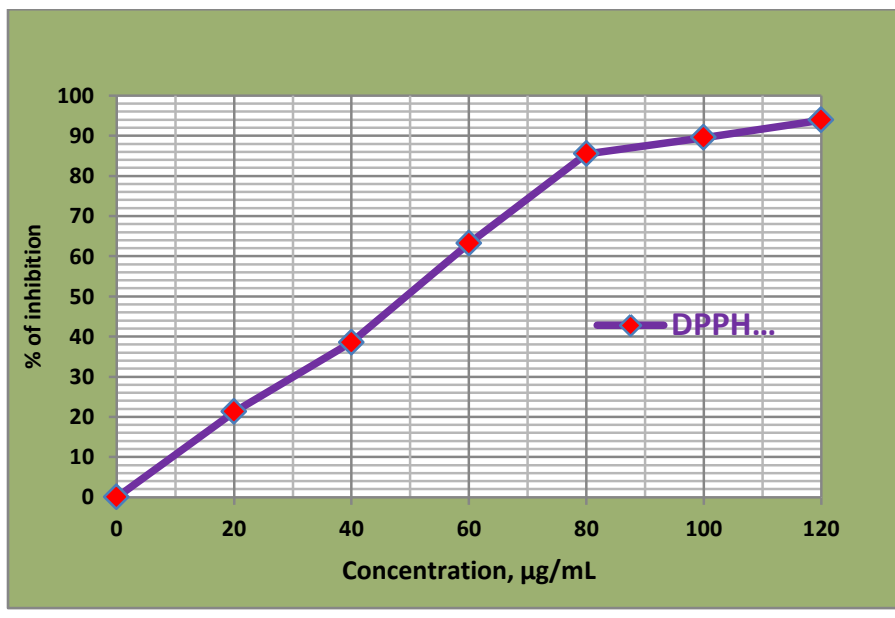

\section{Graph 3.1. DPPH Radical scavenging activity}

\subsection{ABTS $^{\bullet+}$ Radical scavenging activity}

Antioxidant activity was assessed for ABTS •+ radical cation scavenging activity, a blue chromophore was produced in the reaction when ABTS, potassium persulfate and root extract were subjected together, the released cation radical gets reduced and the remaining free radical cation concentration was then quantified [20]. The maximum percentage of $\mathrm{ABTS}^{\bullet+}$ free radical scavenging activity was determined as $52.18 \pm 3.65 \%$ at $60 \mu \mathrm{g} / \mathrm{mL}$ concentration, as shown in Table 3.2 and Graph 3.2. It was compared with the standard ascorbic acid $5.83(\mu \mathrm{g} / \mathrm{mL})$ and $\mathrm{IC}_{50}$ of ABTS ${ }^{\bullet+}$ radical cation scavenging activity was $51.21(\mu \mathrm{g} / \mathrm{mL})$ concentration.
Table 3.2. ABTS ${ }^{\bullet+}$ Radical scavenging activity

\begin{tabular}{|c|c|c|}
\hline \multirow{2}{*}{ S. No. } & $\begin{array}{c}\text { Concentration } \\
(\boldsymbol{\mu g} / \mathbf{m L})\end{array}$ & \% of inhibition \\
\cline { 3 - 3 } & 10 & $\mathbf{A B T S}^{{ }^{+}} \mathbf{a t} \mathbf{7 3 4} \mathbf{~} \mathbf{m}$ \\
\hline 1 & 20 & $14.47 \pm 1.01$ \\
\hline 2 & 30 & $18.51 \pm 1.29$ \\
\hline 3 & 40 & $25.92 \pm 1.81$ \\
\hline 4 & 50 & $43.43 \pm 3.04$ \\
\hline 5 & 60 & $48.82 \pm 3.41$ \\
\hline 6 & & $52.18 \pm 3.65$ \\
\hline
\end{tabular}

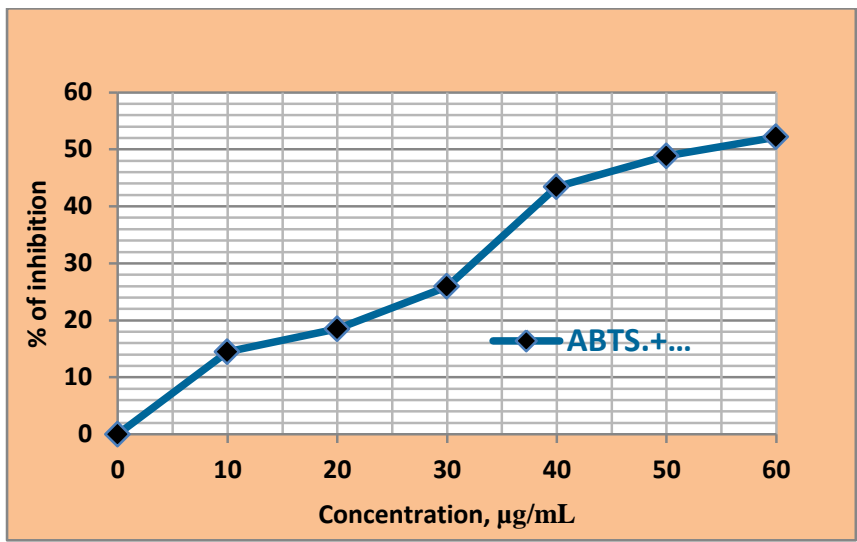

Graph 3.2. ABTS $^{\bullet+}$ Radical scavenging activity

\subsection{Phosphomolybdenum reduction assay}

The total antioxidant activity of root extract of $H$. schulli was measured for phosphomolybdenum reduction assay at $695 \mathrm{~nm}$, where Mo (VI) is reduced to green phosphate/Mo (V) complex at acidic $\mathrm{pH}$ [21]. The maximum absorbance was $86.23 \pm 6.03$ at $120 \mu \mathrm{g} / \mathrm{mL}$ concentrations (Table 3.3 and Graph 3.3), which was compared with standard $3.09(\mu \mathrm{g} / \mathrm{mL})$ ascorbic acid and the $\mathrm{IC}_{50}$ of phosphomolybdenum reduction activity was $107.41(\mu \mathrm{g} / \mathrm{mL})$ concentrations.

\subsection{Ferric $\left(\mathrm{Fe}^{3+}\right)$ reducing power assay}

Ferric $\left(\mathrm{Fe}^{3+}\right)$ reducing power activity was measured in root extract of $H$. schulli at $700 \mathrm{~nm}$. In the assay $\mathrm{Fe}^{3+}$ was reduced to $\mathrm{Fe}^{2+}$ as the concentration of the extract increased, there was increase reducing activity [21]. The maximum reducing activity and free radical scavenger was $62.07 \pm 4.34$ at $120(\mu \mathrm{g} / \mathrm{mL}$ ) concentrations (Table 3.3 and Graph 3.3). The reducing ability increases with the increase in the extract concentration. It was compared with standard ascorbic acid 
$4.50(\mu \mathrm{g} / \mathrm{mL})$ concentration and $\mathrm{IC}{ }_{50}$ Ferric $\left(\mathrm{Fe}^{3+}\right)$ reduction power activity $35.56(\mu \mathrm{g} / \mathrm{mL})$ concentrations.

Table 3.3. Phosphomolybdenum reduction and ferric $\left(\mathrm{Fe}^{3+}\right)$ reducing power assay

\begin{tabular}{|c|c|c|c|}
\hline \multirow{2}{*}{$\begin{array}{c}\text { S. } \\
\text { No. }\end{array}$} & $\begin{array}{c}\text { Concentration } \\
(\boldsymbol{\mu g} / \mathbf{m L})\end{array}$ & \multicolumn{2}{|c|}{ \% of reduction } \\
\cline { 3 - 4 } & & $\begin{array}{c}\text { Phosphomolybdenum } \\
\text { reduction at 695 } \mathbf{~ n m}\end{array}$ & $\begin{array}{c}\mathbf{F e}^{\mathbf{3 +}} \\
\text { reducing } \\
\text { power } \\
\text { at 700 } \mathbf{~ n m}\end{array}$ \\
\hline 1 & 20 & $33.33 \pm 2.33$ & $15.64 \pm 1.09$ \\
\hline 2 & 40 & $56.25 \pm 3.93$ & $28.32 \pm 1.98$ \\
\hline 3 & 60 & $69.23 \pm 4.48$ & $38.61 \pm 2.70$ \\
\hline 4 & 80 & $77.95 \pm 5.45$ & $44.39 \pm 3.10$ \\
\hline 5 & 100 & $82.05 \pm 5.74$ & $46.55 \pm 3.25$ \\
\hline 6 & 120 & $86.23 \pm 6.03$ & $62.07 \pm 4.34$ \\
\hline
\end{tabular}

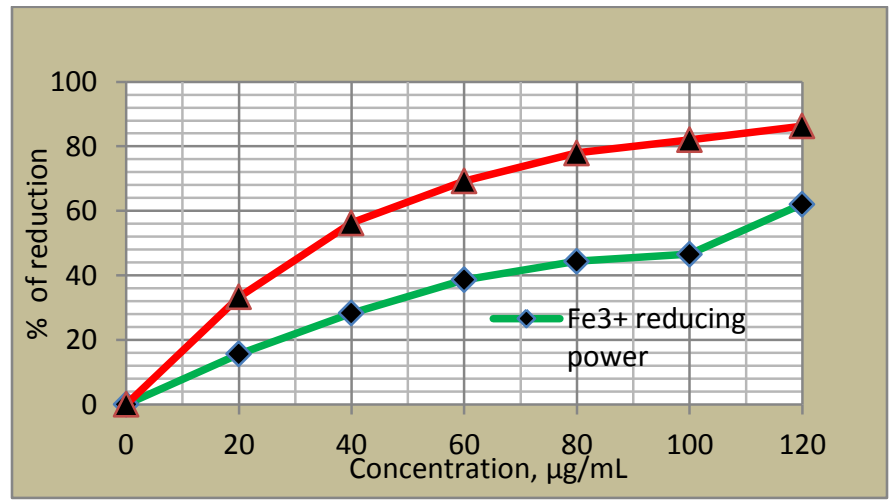

\section{Graph 3.3. Phosphomolybdenum reduction and ferric $\left(\mathrm{Fe}^{3+}\right)$ reducing power assay}

\section{CONCLUSION}

In this study the roots of H.schulli was subjected to various investigations such as DPPH Radical scavenging activity, ABTS ${ }^{\bullet+}$ Radical scavenging activity, Phosphomolybdenum reduction assay and Ferric $\left(\mathrm{Fe}^{3+}\right)$ reducing power assay to study the antioxidant ability and free radical scavenging activity. It was clearly observed in each investigation the maximum percentage of free radical scavenging activity was determined and strong reducing capacity-antioxidant was noted. It was also noted the reducing capacity increased with the concentration of the extract. The results were compared with the standard ascorbic acid and $\mathrm{IC}_{50}$ value of free radical scavenging activity was determined. The result showed increased (reducing capacity) antioxidant activity and is recommended that the root of H.schulli is good source for antioxidant and radical scavenging process.

\section{REFERENCES}

[1]. G.V. Satyavati, and M.K. Raina, "Medicinal Plants of India", Vol.1. Indian Council of Medicinal Research, New Delhi, India. 80: 107, 1976.

[2]. S. Murugan and G.V. Kumar, "Phytochemical Analysis and Antibacterial Activity of Hygrophila schulli (Buch.-Ham.) M.R. Almeida \& S.M. Almeida", International Journal of Green and Herbal Chemistry. Sec. A; 7: 3, 505-512, 2018.

[3]. A. Patra, S. Jha, and P.N. Murthy, "Phytochemical and pharmacological potential of Hygrophila spinosa T. Anders", Pharmacognosy Reviews. 3, 330-341, 2009.

[4]. M.S. Hussain, S. Fareed and M. Ali, "Ethnobotany, phytochemistry and pharmacology of Hygrophila auriculata (K. Schum) Heine", Asian Journal of Traditional Medicines. 5, 122-131, 2010.

[5]. A.K. Maji, S. Pandit, P. Banerji, D. Banerjee, "A Validated RPHPLC Method for simultaneous determination of betulin, lupeol and stigmasterol in Asteracantha longifolia (L.) Nees", International Journal of Pharmacy and Pharmaceutical Science. 6, 691-695, 2014.

[6]. V.P. Kamboj, "Herbal Medicine, Herbal Medicine for Market Potential in India, an Overview", Current Science. 78, 35-7, 2000.

[7]. M. Prasanna, S. Sridhar, "Studies on Antioxidant Activity, Phenol and Flavonoid Content of The Medicinal Plant Hygrophila auriculata", Indo American Journal of Pharmaceutical Science. 4, 306-311, 2017.

[8]. S. Satpathy, A. Patra, M.D. Hussain, B. Ahirwar, "Amelioration of Postmenopausal Osteoporosis and Anticancer Properties of an Antioxidant Enriched Fraction From Hygrophila spinosa $T$. Anders", South African Journal of Botany. 117, 247-255, 2018.

[9]. J.H. Bae, Y.J. Park, J. Namiesnik, I. Gulcin, T.C. Kim, H.C. Kim, B.G. Heo, S. Gorinstein, Y.G. Ku, International Journal of Food Science, Technol. 51, 1378-1385, 2016.

[10]. K. Aksu, F. Topal, I. Gulcin, F. Tumer, S. Goksu, Arch, Pharm. 348, 446-455, 2015.

[11]. M.P. Sridhar, N. Nandakumar, T. Rangarajan, M.P. Balasubramanian, "Amelioraton of mercuric chloride induced oxidative stress by Hygrophila auriculata (K.Schum) Heine via modulating the oxidant-antioxidant imbalance in rat liver", Journal of Biochemical Technology. 4, 622-627, 2013.

[12]. M.H. Sehitoglu, H. Han, P. Kalin, I. Gulcin, A. Ozkan, H.Y. Aboul-Enein, J. Enzyme Inhib. Med Chem. 30, 264-269, 2015.

[13]. Y. Cetinkaya, H. Gocer, A. Menzek, I. Gulcin, Arch. Pharm. 345, 323-334, 2012.

[14]. I. Gulcin, M. Elmastas, H.Y. Aboul-Enein, Arab, J, Chem. 5, 489499, 2012.

[15]. N. Raaman, C. Sivaraj, Tenzing. "Antioxidant activities and phytochemical analysis of methanol extract of leaves of Artocarpus heterophyllus lam", International Journal Pharm Science. 45: 179186, 2014.

[16]. R. Re, N. Pellegrini, A. Proteggente, M. Yang, C. Rice-Evans. "Antioxidant activity applying an improved ABTS radical cation 
decolonization assay Free Radic", Biol Med. 26, 1231-1237, 1999.

[17]. P. Prieto, M. Pineda, M. Anguilar. "Spectrophotometric quantitation of antioxidant capacity through the formation of a phosphomolybdenum complex. Specific application to the determination of Vitamin E", Anal Biochem. 41, 269-337, 1999.

[18]. N. Ravisankar, C. Sivaraj, S. Seeni, J. Joseph, N. Raaman. "Antioxidant activities and phytochemical analysis of methanol extract of leaves of Hypericum hookerianum", Int J Pharm Pharm Sci. 6, 456-460, 2014.

[19]. C. Sivaraj, Y. Aashinya, R. Sripriya and P. Arumugam. "Antioxidant Activities and Thin Layer Chromatographic Analysis of Aqueous Extract of Tubers of Drynaria quercifolia (L)", Free Radicals and Antioxidants. 8(1): 26-31, 2018.

[20]. Vijaya Chavan Lobo, Anita Phatak, Naresh Chandra. "Antioxidant and Free Radical Activity of Hygrophila schulli Seeds". Advances in Bioresearch, Val 1(2), 72-78, 2010.

[21]. S.P. Vardhini, C. Sivaraj, P. Arumugam, Himanshu Ranjan, T. Kumaran, M. Baskar. "Antioxidant, Anticancer, Antibacterial activity and GC-MS analysis of aqueous extract of pulps of Aegle marmelos", The Journal of Phytopharmacology, 7(1): 72-78, 2018. 